\section{Envisioning Science: The Design and Craft of the Science Image} Felice Frankel

(The MIT Press, Cambridge, 2002)

328 pages, $\$ 55.00$

ISBN 0-262-06225-9

Researchers typically spend considerable effort making certain that their scientific images for journal publications and talks are technically correct and easily understood by the intended audience. This book emphasizes another aspect of scientific images that is typically overlooked, namely, their aesthetic visual impact. Using numerous examples taken from her career as a researcher and photographer, Felice Frankel demonstrates how striking images can be made by paying attention to details such as lighting, background, depth of focus, and angles. While retaining their scientific content, such images can greatly enhance the impact of a talk or paper by grabbing the attention of the viewers and directing them to the most important features of the work. An additional benefit is that visually striking images can more effectively communicate ideas to a general (nonscientific) audience than the more typical figures found in technical journals.

The main emphasis of the book is scientific photography; a basic knowledge of photography is assumed. The book is well arranged, with a series of lessons on how to use particular techniques to achieve desired visual effects. Topics include "Basics of Picture Making," "Photographing Small Things," "Photographing through a Stereomicroscope," "Photographing through a Compound Microscope," and "Presenting Your Pictures." In each lesson, beautiful images are included as examples. Often, several imaging conditions are compared to demonstrate how a particular effect can best be used.

Although Envisioning Science is primarily aimed at scientific photography, the basic ideas of image balance, composition, and contrast have much broader applicability. Technical figures, diagrams, computer presentations, and computergenerated images can all benefit from consideration of these ideas. In many cases, just a small additional effort on the part of the scientists can have major positive effects on the visual impact of their work. My only significant complaint about this book is that such extensions outside of photography receive far too little attention (almost none)

The purpose of this book is to engender in the reader a mindset where aesthetics become an integral part of how scientists communicate with their audience. The book is effective, enjoyable to read, and contains strikingly beautiful images with scientific themes. It is well worth reading.

Reviewer: Lyle Levine is a staff physicist at the National Institute of Standards and Technology. He currently does theoretical and modeling work on the atomistic-and dislocationlevel processes underlying the plastic deformation of metals and experimental work on developing new synchrotron $x$-ray imaging techniques such as ultrasmall-angle $x$-ray scattering imaging. Over the years, Levine has done extensive experimental work using many imaging techniques including transmission electron microscopy, scanning electron microscopy, scanning tunneling microscopy, atomic force microscopy, $x$-ray topography, and $x$-ray tomography.

The following recently published books, relevant to materials research, have come to MRS Bulletin's attention. Some of the books listed here may be reviewed in future issues of MRS Bulletin. To review a book from the list or to offer recommendations of additional books, contact K. Wilson, Editorial Assistant, MRS Bulletin, 506 Keystone Drive, Warrendale, PA 15086-7573, USA; e-mail bulletin@mrs.org.

\section{Books}

\section{Materials Processing}

Advances in Joining of Ceramics (Ceramic Transactions, Vol. 138), Charles A. Lewinsohn, Mrityunjay Singh, and Ronald Loehman, eds. The American Ceramic Society, Westerville, OH, 2003, 294 pp., \$57.00, ISBN 1-57498-153-6.

Blow Molding Handbook, 2nd ed., Dominick V. Rosato, Andrew V. Rosato, and David P. DiMattia, Hanser-Gardner Publications, Cincinnati, OH, 2003, 628 pp., \$199.95, ISBN 1-56990-343-3.

Colloidal Ceramic Processing of Nano-, Micro-, and Macro-Particulate Systems, (Ceramic Transactions, Vol. 152), Wei-Heng Shih, Yoshihiro Hirata, and William Carty, eds., The American Ceramic Society, Westerville, OH, 2004, 150 pp., \$109.00, ISBN 1-57498-211-7.

Compression Molding, Bruce Davis, Paul Gramann, Antoine Rios, and Tim Osswald, Hanser-Gardner Publications, Cincinnati, OH, 2003, 196 pp., \$89.95, ISBN 1-56990-346-8.

Extrusion Dies for Plastics and Rubber, $3 \mathrm{rd}$ ed., Walter Michaeli, Hanser-Gardner Publications, Cincinnati, $\mathrm{OH}, 2003,362$ pp., \$99.95, ISBN 1-56990-349-2.

Fabrication of Long-Length and Bulk High Temperature Superconductors (Ceramic Transactions, Vol. 149), Ruling Meng, Amit Goyal, Winnie Wong-Ng, Herbert C.

Freyhardt, and Kaname Matsumoto, eds., The American Ceramic Society, Westerville, $\mathrm{OH}$ 2004, 187 pp., \$109.00, ISBN 1-57498-204-4.
Innovative Processing and Synthesis of Ceramics, Glasses and Composites VII (Ceramic Transactions, Vol. 154), J.P. Singh and Narottam P. Bansal, eds., The American Ceramic Society, Westerville, OH, 2003, 335 pp., \$109.00, ISBN 1-57498-208-7.

Introduction to Drying of Ceramics (with Laboratory Exercises), Denis A. Brosnan and Gilbert C. Robinson, The American Ceramic Society, Westerville, $\mathrm{OH}, 2003$, 253 pp., \$79.00, ISBN 1-57498-046-7.

Joining of Plastics: Handbook for Designers and Engineers, 2nd ed., Jordan Rotheiser, Hanser-Gardner Publications, Cincinnati, $\mathrm{OH}$, 2004, 565 pp., \$129.95, ISBN 1-56990-354-9.

Large Deformation Processes of Solids: From Fundamentals to Numerical Simulation and Engineering Applications, I. Doltsinis, WIT Press, Southampton, UK, 2003, 475 pp., \$249.00, ISBN 1-85312-955-0.

Nanomaterials by Severe Plastic Deformation, M.J. Zehetbauer and R.Z. Valiev, eds. Wiley-VCH, Weinheim, Germany, 2004, 840 pp., \$325.00, ISBN 3-527-30659-5.

Processing of High-Temperature Superconductors (Ceramic Transactions, Vol. 139), Amit Goyal, Winie Wong-Ng, Masato Murakami, and Judith Driscoll, eds., The American Ceramic Society, Westerville, $\mathrm{OH}$, 2003, 388 pp., \$103.00, ISBN 1-57498-155-2.

Thermal Analysis of Welds, N.T. Nguyen, WIT Press, Southampton, UK, 2004, 334 pp., \$198.00, ISBN 1-85312-951-8.

\section{Experimental Techniques}

Handbook of Thermal Analysis and Calorimetry, Vol. 2: Applications to Inorganic and Miscellaneous Materials, M.E. Brown and P.K. Gallagher, eds., Elsevier, New York, 2003, 941 pp., \$299.00, ISBN 0-444-82086-8.

Indentation Techniques in Ceramic Materials Characterization (Ceramic Transactions, Vol. 156), Ahmad G. Solomah, ed., The American Ceramic Society, Westerville, OH, 2004, 162 pp., \$109.00, ISBN 1-57498-212-5.

The Local Chemical Analysis of Materials, Vol. 9, J.W. Martin, Elsevier, New York, 2003, \$120.00, ISBN 0-08-043936-5.

Physical Methods for Materials Characterisation, 2nd ed., P.E.J. Flewitt and R.K. Wild, Institute of Physics Publishing, Bristol, UK, 2003, 602 pp., \$59.99, ISBN 0-75030808-7.

Plastics Flammability Handbook: Principles, Regulations, Testing, and Approval, Jurgen Troitzsch, ed., Hanser-Gardner Publications, Cincinnati, OH, 2004, 748 pp., \$199.95, ISBN 1-56990-356-6.

\section{Structure of Materials}

Nano and Microstructural Design of

Advanced Materials, R. Ritchie, Marc Meyers, and M. Sarikaya, eds., Elsevier, New York, 2003, 500 pp., \$150.00, ISBN 0-08-044373-7. 
Nanophotonics, Paras N. Prasad, John Wiley \& Sons, Hoboken, NJ, 2004, 415 pp., \$84.95, ISBN 0-471-64988-0.

Nanostructures \& Nanomaterials: Synthesis, Properties, \& Applications, Guozhong Cao, Imperial College Press, London, 2004, 433 pp., \$78.00, ISBN 1-86094-412-9.

Nanotechnology: An Introduction to Nanostructuring Techniques, Michael Kohler and Wolfgang Fritzsche, Wiley-VCH, Weinheim, Germany, 2004, 272 pp., \$155.00, ISBN 3-527-30750-8.

One-Dimensional Metals: Conjugated Polymers, Organic Crystals, Carbon Nanotubes, 2nd ed., Siegmar Roth and David Carroll, Wiley-VCH, Weinheim, Germany, 2004, 251 pp., \$150.00, ISBN 3-527-30749-4.

\section{Physics and Electronics}

Interlayer Dielectrics for Semiconductor Technologies, Shyam P. Muraka, Moshe Eizenberg, and Ashok K. Sinha, eds. Academic Press, San Diego, 2003, 480 pp., ISBN 0-12-511221-1.

Introductory Applied Quantum and Statistical Mechanisms, Peter L. Hagelstein, Stephen D. Senturia, and Terry P. Orlando, John Wiley \& Sons, Hoboken, NJ, 2004, 785 pp., \$99.95, ISBN 0-471-20276-2.

\section{Inorganic Chemistry, Electrochemistry,} and Ceramics

Advances in Ceramic Matrix Composites VIII (Ceramic Transactions, Vol. 139), J.P. Singh, Narottam P. Bansal, and M. Singh, eds. The American Ceramic Society, Westerville, OH, 2003, 162 pp., \$87.00, ISBN 1-57498-154-4.

Advances in Ceramic Matrix Composites IX (Ceramic Transactions, Vol. 153), Narottam P. Bansal, J.P. Singh, Waltraud M. Kriven, and Hartmut Schneider, eds., The American Ceramic Society, Westerville, $\mathrm{OH}, 2003$, 346 pp., \$109.00, ISBN 1-57498-207-9.

Bioceramics: Materials and Applications IV (Ceramic Transactions, Vol. 147),

Veeraraghavan Sundar, Richard Pl. Rusin, and Claire A. Rutiser, eds., The American Ceramic Society, Westerville, OH, 2003, 170 pp., \$109.00, ISBN 1-57498-202-8.

Ceramic Armor and Armor Systems (Ceramic Transactions, Vol. 151), Eugene Medvedovski, ed., The American Ceramic Society, Westerville, OH, 2003, 188 pp., \$109.00, ISBN 1-57498-206-0.

Ceramic Armor Materials by Design (Ceramic Transactions, Vol. 134), J.W. McCauley, A. Crowson, W.A. Gooch, Jr., A.M. Rajendran, S.J. Bless, K.V. Logan, M. Normandia, and S. Wax, eds., The American Ceramic Society, Westerville, $\mathrm{OH}, 2002$, 600 pp., \$99.00.

Ceramic Materials and Multilayer Electronic Devices (Ceramic Transactions, Vol. 150), K.M. Nair, A.S. Bhalla, S-I. Hirano, D. Suvorov, W. Zhu, and R. Schwartz, eds., The American Ceramic Society, Westerville, OH, 2004, 490 pp., \$129.00, ISBN 1-57498-205-2.
Ceramic Nanomaterials and Nanotechnology II (Ceramic Transactions, Vol. 148), Mark R. De Guire, Michael Z. Hu, Yury Gogotsi, and Song Wei Lu, eds., The American Ceramic Society, Westerville, OH, 2004, 203 pp., \$129.00, ISBN 1-54798-203-6.

The Chemistry of Nanomaterials: Synthesis, Properties, and Applications, Vols. 1-2, C.N.R. Rao, A. Muller, and A.K. Cheetham, Wiley-VCH, Weinheim, Germany, 2004, 741 pp., \$385.00, ISBN 3-527-30686-2.

Colloids and Interfaces with Surfactants and Polymers: An Introduction, Jim Goodwin, John Wiley \& Sons, Chichester, UK, 2004, 285 pp., \$65.00, ISBN 0-470-84143-5.

Energetic Materials, Part 1: Decomposition, Crystal and Molecular Properties, Vol. 12 P.A. Politzer and J.S. Murray, eds., Elsevier, New York, 2003, 485 pp., \$210.00, ISBN 0-444-51518-6.

Energetic Materials, Part 2: Detonation, Combustion, Vol. 13, P.A. Politzer and J.S Murray, eds., Elsevier, New York, 2003, 474 pp., \$210.00, ISBN 0-444-51519-4.

Environmental Issues and Waste Management Technologies in the Ceramic \& Nuclear Industries VIII (Ceramic Transactions, Vol. 143), S. K. Sundaram, Dane R. Spearing, and John D. Vienna, eds., The American Ceramic Society, Westerville, OH, 2003, 498 pp., \$103.00, ISBN 1-57498-159-5.

Morphotropic Phase Boundary Perovskites, High Strain Piezoelectrics, and Dielectric Ceramics (Ceramic Transactions, Vol. 136), Ruyan Guo, K.M. Nair, Winnie K. Wong-Ng, Amar Bhalla, Dwight Viehland, D. Suvorov, Carl Wu, and S-I. Hirano, eds., The American Ceramic Society, Westerville, OH, 2003, 584 pp., \$103.00, ISBN 1-57498-151-X

Phase Diagrams for Electronic Ceramics I: Dielectric $\mathrm{Ti}, \mathrm{Nb}$, and $\mathrm{Ta}$ Oxide Systems, Robert S. Roth, ed., The American Ceramic Society, Westerville, OH, 2003, 665 pp., \$148.00, ISBN 1-57498-712-2.

Physical Chemistry of Macromolecules: Basic Principles and Issues, 2nd Ed., S.F. Sun, John Wiley \& Sons, Hoboken, NJ, 2004, 549 pp., \$99.95, ISBN 0-471-28138-7.

Silicon-Based Structural Ceramics for the New Millennium (Ceramic Transactions, Vol. 142), Manuel E. Brito, Hua-Tay Lin, and Kevin Plucknett, eds., The American Ceramic Society, Westerville, OH, 2003, 277 pp., \$87.00, ISBN 1-57498-157-9.

Thermal Decomposition and Combustion of Explosives and Propellants, G.B. Manelis, G.M. Nazin, Yu. I. Rubtsov, and V.A. Strunin, Taylor \& Francis, London, 2003, 362 pp., ISBN 0-415-29984-5.

\section{Polymer Chemistry and Biomaterials}

Coloring of Plastics: Fundamentals, 2nd ed.

Robert A. Charvat, ed., John Wiley \& Sons,

Hoboken, NJ, 2003, 430 pp., \$99.95,

ISBN 0-471-13906-8.
Designing Plastic Parts for Assembly, 5th ed., Paul A. Tres, Hanser-Gardner Publications, Cincinnati, OH, 2003, 280 pp., \$79.95, ISBN 1-56990-350-6.

Developments in Block Copolymer Science and Technology, Ian W. Hamley, John Wiley \& Sons, Chichester, UK, 2004, 367 pp., \$165.00, ISBN 0-470-84335-7.

An Introduction to the Mechanical Properties of Solid Polymers, 2nd ed., I.M. Ward and J. Sweeney, John Wiley \& Sons, West Sussex, UK, 2004, 382 pp., \$55.95, ISBN 0-471-49626-X.

Material Science of Polymers for Engineers, 2nd ed., Tim A. Osswald and George Menges, Hanser-Gardner Publications, Cincinnati, $\mathrm{OH}$ 2003, 622 pp., \$79.95, ISBN 1-56990-348-4.

Polymeric Foams and Foam Technology, 2nd ed. Daniel Klempner and Vahid Sendijarevic, eds., Hanser-Gardner Publications, Cincinnati, OH, 2004, 584 pp., \$199.95, ISBN 1-56990-336-0.

Principles of Polymerization, 4th ed., George Odian, John Wiley \& Sons, Hoboken, NJ, 2004, 812 pp., $\$ 98.50$, ISBN 0-471-27400-3.

\section{Metallurgy}

Basic Chemical Thermodynamics, 5th ed., E. Brian Smith, Imperial College Press, London, 2004, 166 pp., \$42.00, ISBN 1-86094-445-0.

Discontinuum Mechanics: Using Finite and Discrete Elements, S. Mohammadi, WIT Press, Southampton, UK, 2003, 308 pp., \$193.00, ISBN 1-85312-959-3.

The Handbook of Advanced Materials: Enabling New Designs, James K. Wessel, John Wiley \& Sons, Chichester, UK, 2004, 645 pp., \$125.00, ISBN 0-471-45475-3.

Introduction to Materials Science, Jean P. Mercier, Gerald Zambelli, and Wilfried Kurz, Elsevier, Paris, 2002, 461 pp. ISBN 2-84299-286-5.

Thermally Activated Mechanisms in Crystal Plasticity, C. Daillard and J. L. Martin, Elsevier, New York, 2003, 500 pp., \$195.00, ISBN 0-08-042703-0.

\section{History, Biography, and Unclassified}

Dictionary of Engineering Materials, Harald Keller and Uwe Erb, John Wiley \& Sons, Hoboken, NJ, 2004, 1314 pp., ISBN 0-471-44436-7.

Forensic Materials Engineering: Case Studies, Peter R. Lewis, Ken Reynolds, and Colin Gagg, CRC Press, Boca Raton, FL, 2004, 438 pp., \$89.95, ISBN 0-8493-1182-9.

Secrets of Ancient Egypt, Peter A. Young, Hatherleigh Press, New York, 2004, 204 pp. \$25.95, ISBN 1-578296-159-7.

Order online 24 hours a day, 7 days a week at www.mrs.org/publications/ 